\title{
The changing forms of corruption in China
}

\author{
Børge Bakken ${ }^{1} \cdot$ Jasmine Wang ${ }^{2}$
}

Accepted: 15 March 2021 / Published online: 27 April 2021

(c) The Author(s), under exclusive licence to Springer Nature B.V. 2021

\begin{abstract}
China's famed growth has created a paradox of huge proportions that is associated with how this development could happen despite the well documented issue of vast corruption. This growth has come through a specific form of corruption, changing from petty theft and speed money to grand theft and access money. The new forms of corruption were made possible through the access to assets like land, mines and State-Owned Enterprises (SOEs) after land-, property-, and SOE-reforms that were implemented during the 1990s. The opaque character of these reforms has led to what can only be described as a climate of grand collusion where officials use their access powers to redistribute what was formerly state-owned assets to themselves and crony entrepreneurs. While the character of corruption has changed over the last decade, the problem has not diminished despite continued official "anti-corruption" campaigns. The Chinese high growth/high corruption model has come with high risks growth and enormous inequality. Historically, Chinese dynasties have grown, decayed and fallen in scenarios similar to that of the present.
\end{abstract}

China's famed growth is riddled with paradoxes related to how this could happen despite the well documented issue of vast corruption. This growth has come through a specific form of corruption. The new model of high growth/high corruption is full of risks and dangerous fall traps. Understanding corruption in requires an indepth examination of the different models of corrupt growth. The anti-corruption campaigns introduced by Xi Jinping is merely a corruption face-lift in the direction suggested by Ang Yuen Yuen. She identifies four aspects of corruption: petty theft, grand theft, speed money, and access money, and argues that corruption can be found on a scale of these four categories [1,2]. While the first three types impede

Børge Bakken

borgebakken@live.com

1 Department of Political and Social Change, Coral Bell School of Asia Pacific Affairs, ANU

College of Asia \& the Pacific, ANU Emeritus Club, The Australian National University,

Canberra, Australia

2 Anthropology, School of Culture, History, and Language, ANU College of Asia \& the Pacific, The Australian National University, Canberra, Australia 
growth, access money (defined as elite exchanges of power and profit) cuts both ways: it stimulates investment and growth but produces serious risks for the economy and the political system. Since the market reforms changed in the early 1990s, corruption in China has evolved toward the access money type. This article explores the economic and historical aspects of Chinese corruption and the effect this has had on the general population. The alleged "anti-corruption" campaigns have focused corruption around the new reality of what could be described as a "grand theft and access money." The need for "connections" (guanxi 关系) and "background" (beijing 背景) between the political elite and entrepreneurs has become a story of grand collusion. Collusion is not cooperation, and elite conflicts have dominated the story of recent Chinese corruption although the weak are always the first victims.

\section{Corruption as growth, decay and collapse: historical and contemporary debates}

Chinese scholars have long debated the importance of historical corruption. Professor Jin Guantao linked the breakdown of former dynasties to the recurring corruption of the imperial system and its “ultrastability" (chao wending 超稳 定). Feudal ultrastability rendered the dynasties inflexible and paradoxically led to instability and collapse when corruption overwhelmed the sitting emperor [3]. Jin's historical criticism was seen as controversial in the 1980s when his book was written because it read as a criticism of the sitting Communist regime at the time of beginning market reforms ([4]: pp. 37-39). In a different, but somewhat parallel argument, professor Qin Hui has argued that historically at the core of the Chinese social fabric lies what he terms an "unjust administrative system" (xingzheng bu zhengyi 行政不正义) leading to the same continuous corrupt practices and repeated breakdowns of the whole imperial system as that observed by Jin Guantao [5]. Instability and breakdown were linked to the feudal focus on such administrative injustice. Throughout Chinese history, corruption and instability repeatedly occurred because the underlying structure focused on "administrative security" (xingzheng anchuan 行政安全) rather than enhancing the welfare of the people. The strategy, according to Qin, led to an unjust and unbalanced power structure that proved unsustainable, ending in social unrest and final collapse. To maintain power became an end in and of itself for the ruling classes throughout the dynastic cycles. Instead of looking for checks and balances, responsibilities and welfare to secure the continuation of the dynasty, rulers were blinded by the privilege of having such tremendous amount of power, paradoxically leading to their own demise. Wu Si adds to Qin Hui's argument of historical corruption and exploitation by describing a phenomenon he calls a "legitimate privilege to injure" (hefa shanghai quan 合法伤害 权). Focusing on the Ming and Qing dynasties, Wu Si shows how officials regularly misused their formal power to exploit the common people. Again, corruption and oppression became core elements of exploitation. "Legitimate" does not mean that this was an act based on a legal code, it was instead one of the "hidden norms" or "hidden rules" (qian guize 潜规则) (also the title of Wu Si's book) or the privilege of the powerful rather than a legalized power to injure and oppress the common people. The practice was implicitly granted to officials from the Imperial state [6]. This privilege still exists in today's 
China, and it is still cruel but profitable. Administrative security is still far more important for the regime than is basic justice and common welfare.

Historical debates in China are often concealed criticism of the present, but the argument of corruption and breakdown also is argued by sociological commentators. Pei Minxin's research based on his many detailed case studies of collusion and corruption among Chinese officials concludes that: "In organizations where collusion is rife, knowledge of corrupt acts perpetrated by colleagues often inspires similar acts. Corrupt leaders in these organizations predictably condone corruption by subordinates. This leads to regime decay... Instead of advancing the regime's interests, they primarily seek private benefits. While proclaiming loyalty to the party-state, they are beholden only to their local patrons, either the party chiefs or the wealthy businessmen" ([7]: p. 263).

Ang Yuen Yuen, compared the "Gilded Ages" of the American past and the present Chinese economic expansion, and discovered that both periods were characterized by widespread corruption and explosive economic growth. Ang argues that China's present struggle with corruption "doesn't mean the country will inevitably collapse... Long-standing Western expectations of Chinese failure have perhaps unintendedly kept the regime alert" ([1]: p. 79). To say that today's China and nineteenth-century America have similar experiences of vast corruption combined with growth does not mean that they are identical experiences. While China is a single party autocracy, the United States is a democracy, although it has recently been re-termed a "flawed democracy" holding only the 25th place on the International Democracy Index [8]. Despite the flaws in the democratic system, Ang argues: "[E]ven during the most corrupt periods, the corrupt mayors and council members could be voted out of office. Transparency mandates, muck-raking journalists, and crusading prosecutors were central ingredients in America's battle against graft in the Progressive Era. Xi, however, spurns bottom-up measures, opting instead to stamp out corruption through the strong arm of the Party apparatus, while expanding the state sector and tightening political control" ([1]: pp. 76-77). Ang's argument does not deny future potential collapse but is rather a perspective that China follows a different path where the lack of a civil society and a free press can delay developments seen in the United States or other democracies. Historical examples - be they paradoxically unstably "ultra-stable" as in Jin's account or dominated by its "unjust administrative system" or "hidden norms" - according to Qin and $\mathrm{Wu}$, clearly has proven to erode and weaken autocracies in a longer perspective.

\section{China and the transparency international corruption perception index}

The most commonly used international indicator of corruption is the Corruption Perception Index (CPI) published on a yearly basis by Transparency International. According to the index, in 2012, the year Xi declared corruption an existential threat to the Party, China was ranked as number 80th out of 174 countries, with a score of 39 out of 100 (where 100 is cleanest). Seven years later, according to the Transparency International 2019 report, China had shown little or no improvement in terms of its standing on the international Corruption Perception Index (CPI). Instead of any improvement, the country had dropped 
four places down to no. 84 out of 183 countries with a slightly higher CPI score of 41. It was on the same level as India at no. 86 with the same score of 41 [9]. Another cross-national perception-based measure of corruption is presented in the World Bank's Worldwide Governance Indicator's Corruption Control Index. Since it was first published in 1996, China has always ranked in the lower half of the countries observed, with no improvement in corrupt activities as a result of the "anti-corruption" campaigns.

Internationally, China has expanded its overseas projects financed by statebacked loans under the so-called "Belt and Road" (yi dai yi $l u$ 一 带 一 路) initiative, an ambitious infrastructure investment plan to build rail, road, sea and other routes stretching from China to Asia, Africa and Europe. The Institute of International Finance 2020 report suggested that China is now the world's largest creditor to low-income countries, with outstanding debt claims on the rest of the world having risen from US\$ 875 billion in 2004 to over US\$ 5.5 trillion in 2019 - more than $6 \%$ of global gross domestic product (GDP) [10]. The latest OECD "Exporting Corruption Progress Report" from 2020 makes clear, however, that: "There have been no known examples of enforcement by China against foreign corrupt practices by its companies, citizens or residents, even though Chinese companies and individuals have been the subject of publicly reported investigations and charges in numerous other countries." China has the lowest level of enforcement registered in the report ([11]: p. 30).

Ang's method of distinguishing different types of corruption allows for a closer look at China and India, both of which seem to be almost identical in terms of corruption according to the CPI rankings. The CPI index, however, is criticized by Ang for seeing corruption as a one-dimensional problem, that measures one score for every country without looking at widely different profiles of corruption. To gain a qualitative aspect to the quantitative CPI measurement, she suggests we should "unbundle" corruption into qualitatively distinct types and then measure them across countries ([2], p. 1). Based on this new typology, Ang suggests and "Unbundled Corruption Index" (UCI) to discover the qualitative differences that the CPI conceals.

\section{The unbundled corruption index}

Ang's paradox is that China has managed to grow despite massive corruption, both before and after announced anti-corruption campaigns. The importance of her explanation of the four different aspects of corruption: petty theft, grand theft, speed money, and access money deserve further exploration. Since the re-start of the market reforms in the early 1990s, corruption in China has been dominated by what she calls access money $([1,2]$, p. 1). In her informative four field table she also illustrates what type involves pure theft and what can be described as mere petty exchanges, looking at how such thefts and exchanges involve non-elite or elite groups $([1,2]:$ p. 8$)$.

Petty theft refers to different ways of stealing, involving misuse of public funds, or extortion among rank-and file government officials on many different levels. In 
my view, this category not only involves the bureaucratic class, but all kinds of elitegroups, be they officials or professionals. Typically, in China, while officials are seen as the most corrupt of all groups, the runner-up group consist of doctors who cheat and exploit patients in different ways (Fun and Zao, 2019). Grand theft refers to more serious types of corruption, like embezzlement or misappropriation of large sums of public money, a privilege reserved for elites placed higher up in the official hierarchy, most seriously among people who control state finances (Fig. 1).

Speed money means petty bribes paid to bureaucrats to speed up the bureaucratic process or jump the queue. Access money refers to high-stakes rewards extended by an elite of business actors to powerful officials. Ang makes the analogy of speed money as "painkillers" while she describes access money as "steroids" ([1, 2]: p. 12). While the first reduces pain, they do not heal the illness and may have serious side-effects. Steroids, on the other hand, are "growth-enhancing" drugs, and come with even more serious side effects. Such "growth steroids" stimulates growth but generates serious risks, and one of the significant social effects is burgeoning inequality. Access money is in many ways an inequality enhancing machine, something that is easy to see in China, now one of a handful of the most unequal societies and perhaps the most unequal in the world [12].

Ang compared 15 different countries illustrated in four field tables emphasizing what type of corruption exists in each. The advantage of such an approach is that it tells more about the character of corruption in each country and thus gives us more information than the single placement on the Corruption Perception Index. We already saw that China and India are nearly identical in terms of corruption according to the CPI. Data from these countries are used in the analysis below to examine qualitative differences in corruption (Fig. 2).

The total problem of corruption may look nearly identical according to the CPI, as India and China are fairly alike according to overall corruption. But the UCI analysis also shows that India is characterized by speed money; daily, petty theftlike bribing practice common in everyday situations. Moreover, China undoubtedly has its fair share of petty theft and speed money too. In different surveys of groups seen as the most corrupt, Chinese respondents have no doubt that the cadre force

Fig. 1 Ang Yuen Yuen's Unbundled Categorization of Corruption. Source: Ang [1]. China's Gilded Age: The Paradox of Economic Boom and Vast Corruption, Cambridge, New York, Cambridge University Press, p. 9

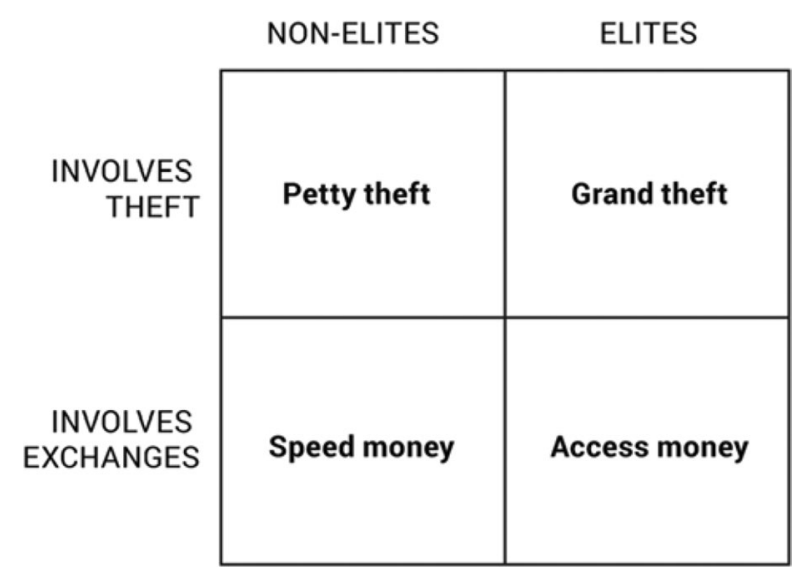




\section{India}

$(27.9 \mathrm{UCl}$ total)

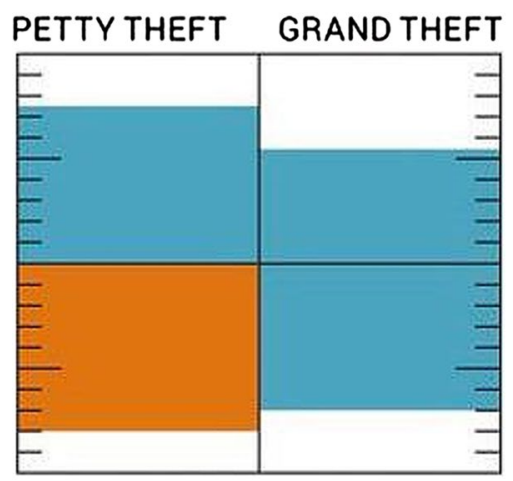

SPEED MONEY ACCESS MONEY

\section{China} (27.2 UCl total)

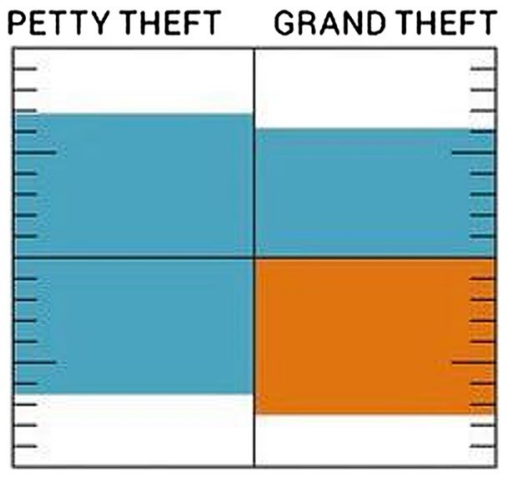

SPEED MONEY ACCESS MONEY

Fig. 2 Unbundled Corruption Index (UCI) Score and Rank of India and China. Source: Ang [1, 2], "Unbundling Corruption: Revisiting Six Questions on Corruption." Global Perspectives Vol.1 (No. 1), p. 6. https://doi.org/10.1525/gp.2020.12036

is the most corrupt, but second to them come the doctors who must be paid petty bribes to speed up sorely needed consultations in order to charge exorbitant prices for the needed medicine ([13]: pp. 20-39). The character of Chinese corruption is dependent on the period under examination. In the late 1980s the opportunities for looting were much more limited because the state-owned assets that became the golden opportunity of crony collusion in the 1990s were not yet accessible. As a result, corruption in the late 1980s was largely confined to conventional forms of petty theft, bribery, and exploitation of rents in government licensing, and the system called dual-track pricing. ([7]: pp. 73-74). Yan Sun's book provides excellent examples and analysis of petty corruption in the 1980s [14]. Regarding types of corruption, speed money corruption is considerably higher than access money corruption in India; in China access money is considerably more prevalent. Though there are still many common traits between China and India, the speed money emphasis of Indian corruption is concentrated more non-elite levels, while the access-money of elite corruption is far more the rule in China. This is the case even though India is not free of access-money and China is not free of speed-money.

In the lower level of officialdom, in China all levels of the bureaucracy have strong incentives to promote development, but different levels of cadres have varying levels of controlling their own activities. Profitable "deal-making" is generally kept away from the lower levels and leaves these decisions to the higher levels of the cadre force. Distinguishing between the activities and the power of the upper level among the political Party selected elite is essential. This upper level includes roughly half a million people, and the fifty million strong rank-and-file members of the entire workforce of officials working on all levels of the State and the Party. 


\section{The formation of access money corruption: land reform, land rights, and SOE property rights reform}

Political and economic reforms transformed the patterns of corruption from a more typical third-world type of petty theft and speed money into what has developed as the central form of corruption in China today, grand theft and access money.

The access money corruption did not start with the market reforms in the early to mid-1980s since there were not yet any massive assets to handle. But this exploded in the 1990s whenever special assets came on the market. The formation of land rights and State-Owned Enterprise (SOE) property rights played an important role in these changes and, at the same time, fostered corruption. Not surprisingly, the real-estate sector is still the hotbed of asset money corruption in China. Real estate generates most of its profits from obtaining cheap land and, together with infrastructure, they comprise the two most corrupt sectors, as since both these involve acquisition of state-owned land.The value of land attracts private entrepreneurs, but since all land is state-owned in principle, these entrepreneurs are unable to get access to such assets alone but must develop connections of political guanxi (关系) through paying bribes in order to be able to manage the bureaucratic maze necessary to develop their projects. Collusion between entrepreneurs and officials is absolutely decisive before any expansion can be made by any entrepreneur. It is no coincidence that a vast majority of the biggest private fortunes in China are concentrated in real estate and mining, the sectors most plagued by collusion. To make this collusion and this special form of corruption possible, there has to be a link to the property rights of land. The specific trait of the party's land reforms is that they decentralized the control of land without clarifying ownership, thus breeding the collusive corruption of asset money and grand theft. A hybrid system developed, in which political power allows access and sets the price of the most valuable asset, land.

As we discuss, the early market reforms gave a lot of discretion and authority over the sale of land to local governments through new rules of decentralizing the way in which the cadres were managed. Decentralization of the cadre management system occurred as early as in 1984, however, the effects of that change did not immediately lead to the explosive development of corruption seen in the 1990s. The reason was that there were no major assets yet to exchange, and the corruption profile remained on a petty theft and speed money stage. With the onset of reforms, however, revenue generated by land sales and the sale of mines could suddenly be stolen by local officials and their business cronies with impunity, and immense profit margins. Local governments could acquire land cheaply, often through sheer coercion, and the cadres on top of the local power bases - particularly the local party chiefs - could make a significant profit by selling land use rights to real estate developers even if the land rights were still nominally state-owned property.

Bribing local officials became normal business practice in order to reach the assets of land and make huge profits. This approach benefited entrepreneurs as well as officials, but mostly the top level in the local administrations, the people who had the authority to allocate land resources and directly determine its price. The control over the regulatory approvals needed to obtain projects also was in the hands 
of local cadres. They could seize land from its current users, mostly the peasantry, but also from urban land holders, using their control of the police and other local institutions. Additionally, the Chinese police are not an independent force of law but are another part of the local administration without central control from upper-level police- or legal institutions. The police naturally became part of the local access money corruption, controlled as they were by the local cadres and not by law.

The other vast resource of the new access money economy occurred when the State- Owned Enterprises (SOE) went up for grabs with the privatization surge during the 1990s. One of the most noteworthy characteristics of the privatization of assets owned by SOEs during the reform era was that it was handled with an unregulated and opaque process [7]. The protagonists of this process also had to move around what they experienced as the mudded waters of widespread opposition against privatization in the Party during the late 1980s and early 1990s. It was only Deng Xiaoping's famous "Southern tour" in 1992, reigniting the liberalization program, that finally made it possible for it to be pushed through. The rules and regulations remained unclear and muddy. The Chinese government, little by little, started to sell off their assets to private entrepreneurs or to officials turned entrepreneurs. An entirely new form of corruption came into being as these groups obtained easy access to the new massive and valuable assets.

These practices are fairly untouched by alleged anti-corruption efforts. The former state managers of SOEs and local officials responsible for liquidating these firms profited immensely, not least because the liquidation process was riddled with loopholes and improvised rules issued by the various ministry-level bureaucracies. The opaque character of the SOE reforms were ideally designed to provide local officials and SOE managers with enormous discretion in carrying out the privatization program. SOE executives who managed to seize state owned assets in this way gained the most from corruption. Given the lax control and the near total discretionary powers enjoyed by SOE executives, asset stripping and theft could easily be accomplished. Some SOEs were changed into joint ventures and transferred to private companies owned by political connections, friends or family at substantial discounts. Another method was "restructuring" or gaizhi (改制). This was in all but name a full privatization transfer through different forms of "mixed ownership" deals. The end-result was often a fully private entity owned by Party chiefs and other top government officials or former senior SOE executives. With the release of the assets of lands, mines and SOEs, a new era of collusion and corruption skyrocketed in China during the 1990s, resulting in the present situation of grand theft and access money.

\section{The decentralized cadre management system: An organizational corruption enabler}

When Xi Jinping took over as Party leader centralization became a focal point,but efforts seem to have stalled. The top leadership seem happy about the present procedures whether or not they are able or unwilling to change the power of the lower levels. The new cadre management system is important in this regard. Before the 
decentralization reforms in 1984 the centralized "managing two levels down" (xiaguan liangji 下管两级) system was in place, making the central leadership able to control the appointment of cadres in provinces and prefectures while provincial Party organizations controlled cadre appointments in the lower level counties. In order to grant local leaders greater and more direct power over cadres in their respective jurisdictions, the cadre management system was reformed in 1984 and replaced by the so-called xiaguan yiji 下管一级)“managing one level down” system. Under the reformed cadre management system, the central leadership managed provincial cadres only. Provincial officials took over the appointment and management of prefecture-level cadres, who in turn were set to manage and appoint county level cadres who could then manage township officials. These reforms significantly empowered the lower levels of the administration, and the local Party chiefs -the “number ones" (yibashou 一 把 手), thereby creating a Party aristocracy with nearly unbridled power with total discretion and no accountability other than the ideological membership in what by some have been termed a "red oligarchy". The talk of “vested interests” (jìdé lìy 既得利䀂) was originally a theme of the emerging anticorruption campaigns. Paradoxically this aspect seems to have been forgotten since the cadre management system does not regard political interests as "vested interests" but rather sees such interests as an honourable membership requirement.

Though there are many examples of local Party chiefs who are taken down by the Central Commission for Discipline Inspection, this occurs when they have abandoned the increasingly strict ideological "basics" and fallen out of grace with the higher-level political elite. The local party chiefs are still the most powerful officials in Chinese local and state institutions, entrusted by the party and given unprecedented power to decide the political agenda. Pei sums up the importance of these decentralized cadre management systems: "It is impossible to overstate the impact of the change from "managing down two levels" to "managing down one level" in facilitating collusion between a local official and immediate subordinate over whom there is now direct power of appointment and promotion" ([7]: 72). Decentralization without accountability can greatly exacerbate corruption at the local level.

\section{High-level access money crimes}

That access money corruption in China is a problem of high-level political corruption can be illustrated by the case against former security czar and Politburo Standing Committee (PSC) member Zhou Yongkang. Falling out with the new administration under Xi Jinping, Zhou was given a life sentence in 2015 but died of cancer shortly after his conviction. Zhou was sentenced for taking 129 million yuan in personal bribes. In addition, Zhou's family allegedly made billions of dollars by investing in the oil industry where Zhou had formerly headed the giant China National Petroleum Corp. Zhou's eldest son allegedly made more than 10 billion RMB from public works in the city of Chongqing alone due to the direct access to his father's power base. He also used his father's position to extort millions of dollars in protection fees from various businesses and organizations [15]. In addition to the bribes, Zhou was sentenced for leaking "top 
secret files". Only his high standing and his confession saved him from immediate execution since corruption is a crime that may result in the death penalty.

The cadre management system of unconstrained power to grant positions in the all- powerful political hierarchy is often referred to by the corrupt practice of "buying and selling of office" or maiguan maiguan (买官卖官) in Chinese. It is a paradox that the system is still in use and even expanded during Xi's reign, since Xi himself has pointed out time and again the grave dangers of the practice. While this system breeds corruption on all levels, some of the big access money corruption cases in China that led to political purges were based precisely on extreme maiguan maiguan crimes. One of the top elite figures who fell in the wake of security tsar Zhou Yongkang's demise was the vice chairman of the Central Military Commission and Politburo member, general $\mathrm{Xu}$ Caihou. Xu gained his fortune by bribes from selling promotions and granting jobs and titles to aspiring People's Liberation officers. Allegedly, a ton of jade, gold, expensive art and cash - 100 million yuan - was taken out of his home in truckloads after his arrest. Commentators have remarked that in terms of $\mathrm{Zhou}$ and $\mathrm{Xu}$, the cases were the results of personal and political power struggles as both men were known to be enemies of the later ultimate leader Xi [16]. This Machiavellian aspect may explain the rapid and prompt action by Chairman Xi, but the general laxness of the "anti-corruption" crackdown in terms of correcting the structural causes for such crimes are hardly changed on the lower levels. Ideological control seems to be the gatekeeper and the ticket to local power. Collusion is effective in reducing the risk of criminal detection, but also involves a Faustian deal of selling your soul to the devil by being implicated in the illegal dealings of your corrupt "mentor" when you are on the receiving side of maiguan maiguan practices.

\section{Corruption and the stressful life of rank-and-file cadres}

That lower-level Party chiefs get more power and are made less accountable for their dealings, does not mean the lower level of rank-and-file cadres have an easier task to perform. On the contrary, the local party chiefs have more direct power and more control over the rank-and-file, making them easier to manipulate and control, and easier to "implicate" in the corrupt dealings of higher local levels of power. "Sharing spoils" is a widespread form of horizontal collusion in government offices and businesses. Direct participation in corrupt activities even solidifies trust among its perpetrators. The process by which an employee is colluding with others to help the company cheat on the taxes is often described as "rational tax avoidance" (heli bishui 合理 避税) in China. If there is one "clean" employee in the team, he or she is regularly seen as "untrustworthy" and discriminated against because this represents a potential danger to the team. This kind of corrupt rationality is also witnessed inside the administrative system, and it is quite normal and escalates corruption, even making rank-and-file cadres complicit, and thus even more loyal to, and dependent on their leaders. An astonishing number of people who were actually caught and prosecuted for corruption confessed that they were spurred on by the widespread corruption they saw around them, feeling obliged 
to act like their comrades-in-arms ([7]: pp. 240-42). The practice is of course not alien to any capitalist organization that has the opportunity to act in corrupt ways.

Qinghua University sociology professor Sun Liping has argued that the strict performance system and the big network of surveillance against cadres are often alienating local cadres who feel an extreme pressure of competition and a growing fear of doing anything wrong. Often the lower level of cadres who are confronted with the daily problems of common persons, are targeted more directly for their faults both from below and above. Sun found that many of the cadres he interviewed as early as 2011 felt that they were "lacking power" or had a "weak" or “marginal" (roushi 弱势) status in society. They sensed they were under constant attack and not in control. This perspective was reported by as many as $45.1 \%$ - nearly half of all the cadres interviewed - the very people who are supposed to be in charge. They had become "passive, panic-stricken, and frightened," according to Sun. ([17]: pp. 22-32). This situation probably escalated after 2012 with the serious onset of anti-corruption campaigns when both the control and the performance criteria of lower cadres were strengthened, making speed money transactions riskier. In other accounts of the situation of rankand-file cadres, we see unreasonable and exploitative expectations against the lowest cohort of local cadres, who as a result suffer from exhaustion, insomnia and depression ([18]: pp. 40-62). Such observations are confirmed by Ang who concludes that: "My analysis finds a remarkably high turnover rate, indicating extraordinarily stressful conditions and heightened political risks for local leaders. Facing harsh scrutiny, volatility, and mounting demands, bureaucrats feel paralyzed, precipitating a new problem in Chinese politics - inaction" ([1]: p. 21). This situation must also be seen in the light of the low regular wages of this part of the cadre force. Still, however, it is easier for a cadre to stay clean than it is for the private entrepreneur. For the latter it is virtually impossible.

\section{Increasing the barriers of Élite entry: the red Élite vs. the Grassroot entrepreneur. The case of tech-Giant ma Yun}

In late 2020, Chinese regulators launched an investigation into Alibaba, China's biggest e- commerce giant. The company's co-founder Ma Yun - or Jack $\mathrm{Ma}$ - "disappeared" and was allegedly arrested and in detention. In late October 2020 the tech billionaire gave a controversial speech, criticizing China's financial watchdogs and banks, claiming that China's financial sector basically was an out-of-date system. [19]. He was not seen in public after his controversial speech until three months later. Forbes lists Ma's net worth at nearly US\$60 billion, making him the second richest man in China and the twentieth richest person in the world. His wealth, however, still could not protect his vulnerable position.

The State Market Supervision Administration issued a statement that it had filed an antitrust investigation into Alibaba Group Holdings Ltd. over their "suspected monopolistic practices". The company was also ordered to pay a fine of half a million RMB for breaching the anti-competition law. This incident was the first time the top market regulator had gone after a Chinese hi-tech giant, and it has been seen as a stark warning against anyone who dare step over the invisible 
line of publicly criticizing the Party's policy and the basic financial institutions in the country. China's internet giants apparently had become too powerful and needed to be held accountable to prevent exclusive market domination. The techgiants clearly pose a big challenge to the monopoly of the State-owned Chinese banking industry.

Ma was also seen as an outsider not fully worthy of a membership in the political élite. There is a description for people like Ma Yun in Chinese - hongding shangren (红顶商人) - perhaps best translated as "red high-flyer", someone with a high level of both ambition and ability. The concept originally referred to people who had a dual identity of being both an official and a businessman, but now broadly refers to businessmen who have good relations with important top-level officials. Ma Yun, however, does not have the "red" credentials or background as some other hongding shangren, as he is often seen as a caogen de hongding shangren (草根的红顶商人) or a red highflyer with a "grassroots" background. Ma Yun serves as an example that the ladder to the elite is drawn up on ideological "hereditary" grounds. The "hereditary red" elites are increasingly skeptical towards people with Ma's background, a mere grassroots entrepreneur, particularly when they start to talk freely. A "red highflyer from the grassroots" is an oxymoron for the red élite, and no longer trustworthy in the eyes of the leading echelons of the Party. Ma illustrates the risks stowed upon entrepreneurs with insufficient political backing and an independent voice, however big they have grown. In many ways, Ma, even as different as he was from other Russian kleptocrats, may now be playing the role of the weakly or non-politically aligned private capitalists in Putin's Russia, a group eliminated by Putin's political apparatus as they posed a threat to his own political power élite. In China, the political élite has managed to keep the control over private entrepreneurs although they have always been dependent on them. Politics still manifestly defines this game, both in Russia and China. The Ma case also illustrates the recent increasing weight on ideological "redness" as the safest way to secure red oligarchy privilege. The Ma Yun story tells us that his type of creative entrepreneur - who came to power and wealth through his collusion with the political elite - first possess far greater talents than political élites in making the assets they dispose far more productive. Such entrepreneurs are also far more able to make the assets at disposal appreciate in value. Second, however, like the Greek myth of Icarus who tumbled from the sky and drowned in the ocean when the wax that held his wings together melted when he flew too close to the sun, Ma's wax of collusion seemed to stop his flight when he had climbed too high. He may not have drowned like Icarus, but he was certainly wing-clipped. The Ma case shows that the red élite are escalating the high barriers of entry to the exclusive club of wealth and power, and the ideological and hereditary recruitment criteria seem to have been strengthened in a clear case of telling the entrepreneurial class who is in power. This development is also seen in lower levels of the entrepreneurial side of the great collusion [20]. Ordinary Chinese citizens, however, can only watch the fight of the self-appointed giants of wealth from afar. 


\section{The economic and social effects of asset money corruption: debt, unproductive over-investment, inequality and "negative welfare"}

The threats facing China today, despite initial successful growth, both in terms of the general economy and in terms of styles of corruption, lies in unproductive overinvestment and excessive debt, fueled by access money. Economists Klein and Pettis' explanation of China's investment-led growth model is useful reading because it focuses on the link between an exploitative attack on household consumption and savings and a continuing unproductive investment strategy that has very much to do with the asset-stripping reality of the Chinese economy. Pettis is based at Beijing University, and many people in the party leadership pay attention to his analyses, some with great interest and reflection, and some likely with a sense of panic. The economists argue convincingly that Chinese leadership pushed an economic model that funded investment at the expense of consumption, funneling household savings to preferred companies through an opaque state-controlled banking system. This "betting-on-the strong" strategy had a detrimental effect on the private economy and consumption. This is an overlooked aspect when we hear the uninformed praises of China "bringing hundreds of millions out of poverty." There is little discussion of how asset-stripping and corrupt investment strategies actually pushed many into poverty. The fate of many systematically discriminated migrant workers has become what Marxists once called "the right to sleep under the bridges". While joblessness is called “waiting for work" (daiye 待业), an equally euphemistic weasel-word explains that the city slums, the so-called "urban villages" (chengzhongcun 城中村) where migrant workers congregate in the millions cannot be described as "slums", but by the official euphemism of “areas awaiting prosperity" (daifu qu 待富区). Language is also power.

The sacrifice of household consumption on the altar of investment, Klein and Pettis argue: "is self-defeating if the result is excess capacity and impoverishment of workers - precisely the situation in China since the early 2000s." They further argue that investments are worthwhile only if they satisfy unmet consumption needs. Otherwise, "investments are just wasteful misuses of resources that could have been better deployed elsewhere." In fact, from the early 1990s when the asset-stripping fueled investment strategies of the party and tens of millions lost their jobs and their welfare support, "[T]he Chinese government began to implement a variety of mechanisms to transfer spending power from ordinary Chinese for the sake of subsidizing domestic investment and foreign consumption. China's rapid growth helped hide the scale of these transfers from ordinary Chinese workers and retirees" ([21]: p. 108). Until 2008, they argue, China's underlying economic potential - reflected through investment projects - had more or less reached its peak. The catastrophic quest to "meet the state grain quotas" during the "Great Leap Forward" that lead to the catastrophic famine years and the death of tens of millions finds an eerie parallel in present-day China. In order to "meet the GDP growth target" local governments are still highly motivated to generate economic activity through unprofitable investment projects and fake statistics. The targets of investment are the same assets that has driven the special type of corrupt 
activities in China for years. Klein and Pettis explain that: "The easiest way for officials to hit their targets is therefore to tell the state-run banks to lend to favored companies to invest in as much infrastructure, manufacturing, and real estate as necessary. Whether the investments are worthwhile is irrelevant. All that matters is that quantity of spending generates enough reported GDP to meet the central government's objectives" ([21], p. 115). Of course, this incentive is not only about "meeting GDP growth targets." The unproductive investment strategy continues because it is also about keeping the "golden egg" structure that triggered access money corruption in the first place.

Consequentially, the enormous debt problem continues, and the growth in debt exceeds the growth in China's debt capacity. The Institute of International Finance (IIF) estimated that China's total domestic debt rose to $335 \%$ of the country's gross domestic product (GDP) in the third quarter of 2020 [10].

Klein and Pettis' emphasis on unproductive investment strategies, debt and the transfers from ordinary Chinese workers and retirees highlights the problem of inequality. Moreover, the falsified Gini coefficient officially allowed for the World Bank to publish has been set by Chinese authorities to 0.38. Internal World Bank estimates, however, set the real Chinese Gini to 0.612 in 2012. This places China among a handful of the most unequal societies in the world today. The higher estimate is confirmed by several researchers in the field ([22], p. A6; [12, 23]).

An extreme example illustrating both the unproductive building-spree investment problem and the debt problem is found in the experiences of Dushan, a backwater rural county in Guizhou Province with a population of 370,000. The county racked up 40 billion yuan (US $\$ 5.7 \mathrm{bn}$ ) in debt with dozens of white-elephant projects. The county received major attention after a video went viral with tens of millions of viewers social media after China's top discipline watchdog, the Central Commission for Discipline Inspection, used Dushan's fiscal recklessness as an example of public officials misusing their authority. Starting in 2016, constructed scenic sites, industrial parks and a wooden skyscraper were built to boost the economy, but instead remained unfinished as idle white elephants. The Dushan county government made a predictable "self-criticism" about their reckless borrowing, debt and performance boasting, and the county's Party secretary who was found to be responsible for the havoc, was charged with taking bribes and for covering up illegal land use [10, 24, 25]. The problem, however extreme, is not at all atypical but describes a trend that is seen in numerous counties all over China.

Interviews by the authors tell of scores of counties in South and South-West China facing serious debt issues. Some counties even failed to pay for their own cadres during parts of the year. In many cities a phenomenon called "high-priceno-market" (youjia wushi 有价无市) has been observed over the years. Real estate values could be held artificially high by the visible hand of the party by reporting high occupancy rates even when vacancy rates were massive, in order to prevent a drastic fall in housing prices. Interestingly, Dushan County remained on the list of poverty-stricken counties in China until March 2020. Thus, many counties want to sit on that seemingly dishonourable list since a poverty-stricken county is automatically granted the privilege of requiring aid from upper- level prefectures or district governments. 
More widespread crime is yet another consequence of corruption. In general, corruption is correlated with violent crime, and China is no exception. Law enforcement corruption and mafia-like influence in such corruption is a well-known fact throughout the world. A large number of senior police officers in China have been arrested and sentenced for corruption. The court system is also heavily involved in corruption. Criminals even know the exact sum of a bribe to have a sentence reduced or completely cancelled [26]. The difference between an average private entrepreneur who typically resorts to bribery, and a crime boss, is that the latter mixes bribery with intimidation and direct violence. In some areas of China, mafia organizations have entirely taken over the political leadership. ([7], pp. 243-55).

The correlation between corruption and organized crime is well established [27]. It is also well-documented that China is among the most unequal societies in the world.

Inequality and violent crime, in particular homicide, is one of the highest and well- established correlations in criminology [28]. The practice of falsifying crime rates and statistical data in general is endemic in China. The country's homicide rate is listed as among the lowest in the world, but internal sources show they were already at the level of the United States as early as 2006 [12]. The cycle of corruption-inequality-violence has much closer links than acknowledged by the regime .

The following is a reiteration of what happened during the release of state assets during the 1990s. SOE executives and selected party members and their connections could buy what was formally state-owned assets at a low price with the excuse of “property rights reform” (chanquan gaige 产权改革), “SOE restructuring” (guoqi gaizhi 国企改制) or “SOE reforms” (guoqi gaige 国企改革). They laid off employees on a massive scale in a so-called “downsizing program" (jianyuan zeng xiao 减 员增效) in order to increase the efficiency of production output before the private and semi-private asset take-over. From 1995 to 2002 over 40 million jobs in the state sector were cut, along with nearly 30 million jobs lost in the manufacturing, mining, and utilities sectors. This restructuring continues today. In 2016, China officially announced another layoff of nearly two million workers. Reuters, however, citing anonymous sources close to China's leadership, put the true figure at five to six million from 2016 to 2018 alone. Aware of the potential social instability due to the layoffs, a rescue packet of 100 billion RMB to find new employment was announced for the new millions who would lose their jobs to restructuring. Publicly, Chinese authorities seem confident that growth in the service sector can absorb most of the layoffs from heavy industry [29]. It is still unclear how this has worked during the slow-down due to the Covid-19 crisis in 2020.

Prior to the wave of restructuring reforms and the sell-off of land, mines and SOEs to the new oligarchy, state sector employees that made up the vast majority of China's workforce enjoyed the benefits of the socialist policy of the so-called "iron rice bowl" (tie fanwan 铁饭碗) - a job security guarantee along with social benefits such as healthcare and pensions provided by the state. After restructuring and the stripping of assets, the workers have experienced what Qin Hui describes as a strategy of Chinese “negative welfare" (fu fuli 负福利).. China has effectively established a negative welfare system, Qin argues, that virtually robs the poor to feed the rich (jiepin jifu 劫贫济富) [30]. 
The current problem is that China's "Gilded Age" boom period of breakneck economic growth is winding down, although there is no guarantee that the vast corruption that followed in its wake will end, nor that the extreme wealth gap will narrow. On the contrary, with growth slowing, it is an open question whether China's private sector, particularly dependent on service industries, will be able to provide enough jobs to curb the resulting social upheaval. Whether this situation will lead to a breakdown scenario or not is unknown. The incentives of the red élite and the upper echelons of the cadre force to keep their profit-sharing model is strong, albeit it benefits the few and not the general population. The present growth model rewards leaders and bureaucrats linked to economic performance, and élites in control of unconstrained power cannot resist using it to loot the wealth generated by economic growth.

\section{Conclusion}

Popular sayings in China reflect the resentment against corruption. One such adage from the late 1990s noted: "If you execute all the cadres for corruption, you will kill some innocent people. If you execute half of the cadres for corruption, many guilty ones will be let off the hook." Even scholarly literature at the time confirmed that at least half the cadre force was involved in corrupt practices [31]. Chen Yun, one of the first-generation CCP leaders, died at the age of 90 in 1995. $\mathrm{He}$ is alleged to have commented on the risks and possibilities of corruption: "Fight corruption too little and destroy the country. Fight corruption too much and destroy the party." Xi may have listened to the old party giant's words. His anti-corruption strategy has in many ways been successful, not in terms of reducing or halting corruption, but in creating the atmosphere of an effective system of anti-corruption. The daily speed money type of corruption - the easiest form to discover among the public - has been curtailed through the shift in corruption structure and practices. Pei concludes that the anti-corruption campaign strategy has meant "an immense boost" in Xi's political capital, and that it also represented "an effective way of dismantling the patronage networks of his political rivals" - although the strategy is also rife with risks of political decay or breakdown ([7]: pp. 264-65). The emerging middle-class tend to deny that China has a serious corruption problem at all. Even if many still cannot afford to jump the queues in hospitals and have to pay "red pocket money" to rank-and-file officials to be able to solve all kinds of everyday difficulties, this problem of petty theft is clearly lessened compared to a decade or two ago. Access money corruption may not be as visible as speed money corruption, unless one is among those who lost their jobs in the SOE takeovers, or unless one is among those who were removed from their land or had their house illegally demolished because of covert development deals. These realities reveal that it is a serious misconception to assume that access money corruption does not negatively affect vast numbers of the Chinese population. Moreover, this form of corruption also leads to a continued systematic increase in inequality. For the upper middle classes and the rich benefitting 
from the system, however, the profits coming from the new type of corruption is often seen as a "natural" phenomenon and as a form of entitlement.

The growing social and economic division in China between rich and poor created by the dominating growth model may be kept in check by the historical resilience of the CCP and the expansion of the security state. The lack of a civil society and a free press replaced by propaganda and surveillance may still keep social unrest in check although the system is far from the effective "digital dictatorship" often referred to in Western media. As we have seen, however, the historical evidence indicate that the "Mandate of Heaven" eventually comes to an end in autocratic societies. In the past, China's dynasties have emerged, formed, decayed and fallen over and over again. Only the future will show how long the high corruption, high growth scenario can function and last.

The centrality of corruption in China has parallels with an old Norwegian folktale that exists in many versions. An old peasant woman was going to load logs on the horse-sleigh to drive them home to the farm, but she did not know how much she was going to put on. When she had put one on, she said to the horse: "If you pull this one, you pull this one, and if you pull that one, you pull that one." And so she continued to add logs, until the horse could not pull the load at all. In one version the horse even died in the effort, and in another the old lady started taking off one $\log$ after the other and ended up with nothing at all. The folktale tells us that even if the CCP manages to pull that one and this one time and again as in the past, the result experienced by the old woman and her horse may still ultimately occur.

Data availability Not applicable.

Code availability Not applicable.

Declarations

Conflict of interest Not applicable.

\section{References}

1. Ang, Y. Y. (2020a). China's gilded age: The paradox of economic boom and vast corruption. Cambridge University Press.

2. Ang, Y. Y. (2020b). Unbundling corruption: Revisiting six questions on corruption. Global Perspectives, 1(1), 1-19. https://doi.org/10.1525/gp.2020.12036.

3. Guantao, J (1983). Zai lishi de biaoxiang beihou: Dui Zhongguo fengjian shehui zhao wending jiegou de tansuo (在历史的表象背后一对中国封建社会超稳定结构的探索) (Behind the Phenomenon of History: A Discussion of the Ultrastable Structure of the Chinese Feudal Society), Sichuan renmin chubanshe (Sichuan People's Publishing House).

4. Bakken, B. (2000). The exemplary society. Human improvement, social control, and the dangers of modernity in China. Oxford University Press. 
5. Hui, Q. (2019). Chuantong shilun: bentu shehui de zhidu, wenhua ji biange” (传统十论: 本土社 会的制度、文化及其变), (Ten theories of Tradition: System, Culture, and Reform of our Native Society, Shanxi renmin chubanshe (Shanxi People's Publishing House).

6. Wu, S. (2009). Qian guize: Zhongguo lishi zhong de zhenshi youxi (中国历史中的真实游戏), (the hidden rule of officialdom in ancient China (revised edition) Yunnan renmin chubanshe (Yunnan People's Publishing House).

7. Pei, M. (2016). China's crony capitalism. The dynamics of regime decay. Harvard University Press.

8. Democracy Index (2019). A year of democratic setbacks and popular protest, Economist Intelligence Unit (EIU). https://www.eiu.com/public/topical_report.aspx?campaignid=democracyindex 2019.

9. Transparency International Corruption Perceptions Index (2019). https://www.transparency.org/en/ cpi/2019).

10. Lee, A. (2020). China debt: how big is it and who owns it?, South China Morning Post, 19 May 2020. https:// www.scmp.com/economy/china-economy/article/3084979/china-debt-how-big-it-who-owns-it-and-what-next.

11. Dell, G. (Lead author). (2020). Exporting Corruption Progress Report 2020: Assessing Enforcement of the OECD Anti-Bribery Convention, https://images.transparencycdn.org/images/A-slim-versionof-Exporting-Corruption-2020.pdf.

12. Bakken, B. (forthcoming). Crime and control in China. The myth of harmony. Polity Press.

13. Fun, Y., \& Yao, Z. (2019). A state of contradiction: Medical corruption and strain in Beijing public hospitals. In B. Bakken (Ed.), Crime and the Chinese dream (pp. 20-39). Hong Kong University Press.

14. Sun, Y. (2004). Corruption and market in contemporary China. Cornell University Press.

15. Pin, H., \& Huang, W. (2013). A death in the lucky holiday hotel: Murder, money, and an epic power struggle in China. New York: Public Affairs

16. Associated Press (2014). Chinese anti-corruption crackdown nets former top general, 1 July 2014. https://www.theguardian.com/world/2014/jun/30/chinese-anti-corruption-crackdown-former-topgeneral.

17. Sun, L. (2011). “Zouxiang jiji de shehui guanli” (走向积极的社会管理) (Towards a proactive social management), Shehuixue yanjiu (Sociological Research), No. 4, pp. 22-32).

18. Sorace, C. (2016). Party Spirit made flesh: The production of legitimacy in the aftermath of the 2008 Sichuan earthquake. The China Journal, (Issue 76, July), 40-62.

19. Fang, J. (2021). Alibaba under investigation amid speculation over Jack Ma's 'disappearance', ABC 10 January, https://www.abc.net.au/news/2021-01-10/alibaba-investigation-amid-speculation-jackma-whereabouts-china/13042044.

20. Osburg, J. (2019). Corruption, anti-corruption, and dynamics of class formation in post-Mao China. In D. J. Solinger (Ed.), Polarized cities: Portraits of rich and poor in urban China (pp. 149-168). Rowman \& Littlefield.

21. Klein, M. C., \& Pettis, M. (2020). Trade wars are class wars: How rising inequality distorts the global economy and threatens international peace. Yale University Press.

22. Agence France-Presse (2012). China "Is among World's Most Unequal Nations. South China Morning Post, A6.

23. World Bank (2020) official Gini index, https://data.worldbank.org/indicator/SI.POV.GINI (Accessed 20/02/20).

24. GCR Staff (2020). Rampage of white elephants: Tiny Chinese county racks up \$5.7bn debt with dozens of vanity projects. Global Construction Review, 16 July 2020. https://www.globalconstruct ionreview.com/news/rampage-white-elephants-tiny-chinese- county-racks-/.

25. Ye, Y. (2020). Unfinished Vanity Projects a Debt Trap for Guizhou County, Sixth Tone, 14 July 2010, https://www.sixthtone.com/news/1005931/unfinished-vanity-projects-a-debt-trap-for-guizh ou-county.

26. Xi, Z. (2019). 'Cake uncles': Formation of a criminal town in rural China, pp. 40-72. In B. Bakken (Ed.), Crime and the Chinese dream. Hong Kong University Press.

27. Gounev, Philip, Tihomir Belzov (2010), Examining the links between organised crime and corruption, Sofia: Center for the Study of democracy, European Commission. Director- General for Justice, Freedom and Security. https://csd.bg/publications/publication/examining-the-links-between-organ ised-crime-and-corruption/. 
28. Rufrancos, H. G., Power, M., Pickett, K.E, \& Wilkinson, R. (2013). Income Inequality and Crime: A Review and Explanation of the Time- series Evidence, Social Criminology (1:1) https://doi.org/ 10.4172/scoa.1000103.

29. Tiezzi, S. (2016). China's Coming Mass Layoffs: Past as Prologue? The Diplomat, 3 March 2016. https://thediplomat.com/2016/03/chinas-coming-mass-layoffs-past-as-prologue/.

30. Hui, Q. (2013). Nanfei de qishi (南非的启示), (The South African Inspiration). Jiangsu wenyi chubanshe (Jiangsu Literature and Art Publishing House).

31. Manion, M. (2004). Corruption by design, building clean government in mainland China and Hong Kong. Harvard University Press.

Publisher's note Springer Nature remains neutral with regard to jurisdictional claims in published maps and institutional affiliations. 